Animal Health Research Institute, Alexandria.

\title{
APPLICATION OF HAZARD ANALYSIS CRITICAL CONTROL POINT (HACCP SYSTEM) IN THE PRODUCTION OF UHT MILK TO PRODUCE SAFE AND HIGH QUALITY PRODUCT
} (With 3 Tables)

\author{
By \\ A.S. AIAD \\ (Received at 20/9/2008)
}

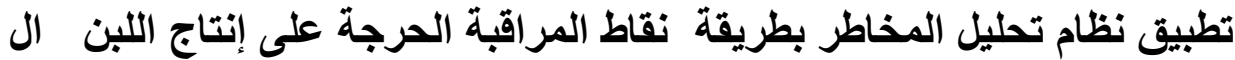
UHT لتقديم منتج آمن وعالى الجودة

$$
\text { أحد صلاح اللدين عياد }
$$

يعتبر اللبن غذاء يقارب الكمال لأنه يحتوى على أهم العناصر التى يحتاجها الإنسان فى كافة فئة

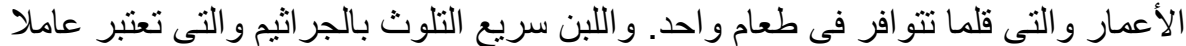

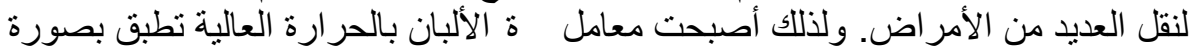

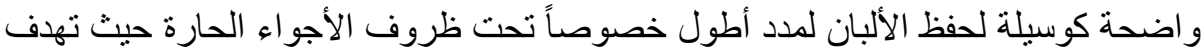

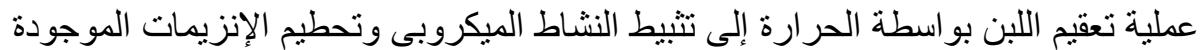

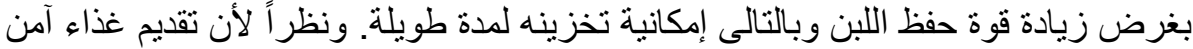

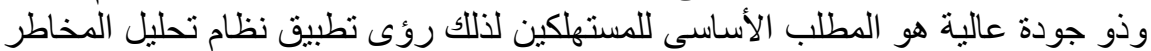

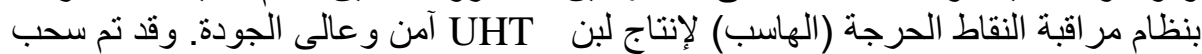

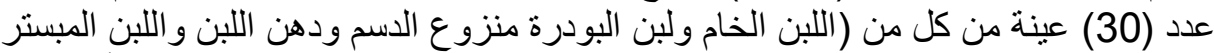

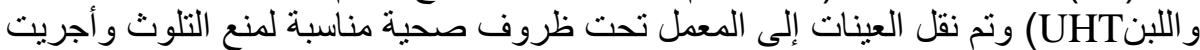

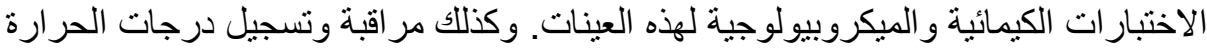

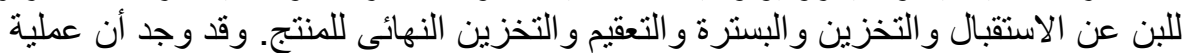

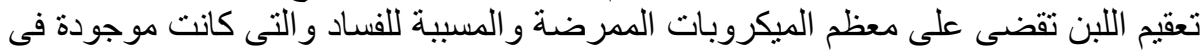

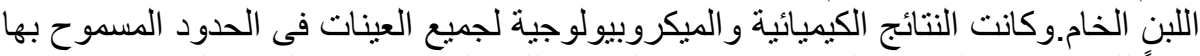

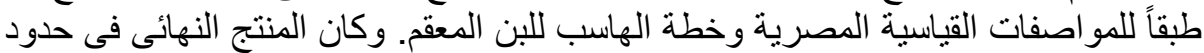
متطلبات الجودة والأمان. وقد تم مناقثة النقاط اللازمة لإنتاج لبن معقم آمن وذو جودة النّان عالية. 
The application of hazard analysis critical control point (HACCP) system principles and required tasks were carried out in a Dairy products processing plant in Alexandria- Egypt. Objective of this study is to evaluate the chemical and microbiological specification of sterilized milk through the application of HACCP system to produce high quality and safe product. Random samples were taken during monitoring of processing line for verification purpose 30 samples from each of raw milk, skim milk powder, milk fat, pasteurized and sterilized milk for chemical and microbiological examination. Samples were taken and transferred directly to the laboratory under aseptic condition with a minimum of delay. The samples were then subjected to chemical and microbiological examination. The obtained results revealed that the mean values of total aerobic bacterial count $(\mathrm{cfu} / \mathrm{ml})$, coliform count, staphylococcus aureus count, spore forming count and mold count in raw milk samples were $3.4 \times 10^{5} \pm 1.7 \times 10^{5}, 3.2 \times 10^{4} \pm 1.9 \times 10^{4}, 6.5 \times 10^{2} \pm$ $1.8 \times 10^{2}, 3.9 \times 10^{2} \pm 2 \times 10$, and $1.9 \times 10^{2} \pm 5.6 \times 10$, respectively. The reduction rate in microbial counts in pasteurized and sterilized milk were $99.18,100,97.16,100,92.15,100,81.28,91.28,100,100$ respectively. UHT treatment of milk killed all pathogenic microorganisms which were present in raw milk and the UHT milk nearly sterile except small incidence (5\%) with low spore forming count. The chemical and microbiological results were within acceptable limits according to Egyptian standards. (ES 2005). The results of monitoring the processing line revealed that the line was well controlled and within the limits of prescribed HACCP plan. Conclusion, AHACCP based risk assessment and good manufacturing practice should be employed for all stages of production and handling of sterilized milk from the farm to the consumer. The production of sterilized milk under the application of HACCP system can assume both quality and safety of the final product. Pasteurization can be used as critical control point to control microbial hazards. It is recommended that the HACCP system be implemented in all dairy industry to improve quality and safety of sterilized milk.

Key words: HACCP - pasteurized milk - UHT milk 


\section{INTRODUCTION}

The hazard analysis critical control point system is a science based and systematically identifies specific hazards and measures for their control to ensure the safety of food. HACCP is a tool to assess hazards and establish a control system that focus on prevention rather than relying mainly on end product testing (Codex 2000). The HACCP method of food safety control is accepted as the best way to assure consumer safety in the production of foods, it is a preventive approach to food safety management (Early, 1997). Pasteurization and sterilization are the most common used heat treatment they are performed on a large industrial scale due to the need for qualified, experienced staff and strict controlled hygienic processing condition. Milk pasteurized by a special method involving ultra high temperature is called UHT milk. This process extends the shelf life of the milk without changing the nutrient value. The term sterilization refers to the complete elimination of all microorganisms. Ultra heat treatment is partial sterilization of milk by heating it for a short time at temperature exceeding $135^{\circ} \mathrm{C} / 4$ seconds which is the temperature required to kill spores in milk. UHT milk has atypical shelf-life of six to nine months, Pasteurized milk has a relatively short life and should be used immediately or stored in the refrigerator while sterilized milk keep unopened for several months and once opened the milk must be kept refrigerated.

The main potential hazards in most dairy products are microbiological hazards and the dairy industry has increased its efforts for quality and safety assurance through the development and implementation of protective programmes as HACCP (Kassem et al., 2002). Although UHT milk is processed in a manner makes its validity time longer than other heat treated milks (pasteurized and boiled), yet its shelf-life may be shortened due to same undesirable chemical or microbiological changes induced by certain microorganisms or their related heat resistant lipolytic or proteolytic enzymes that render such product of inferior quality or even un marketable (Abo-Donia et al., 1985). UHT milk may be contaminated with relatively high counts of viable aerobic bacteria, aerobic spore-formers and fungi. This may be due to inefficient heat treatment of processed milk, faults in packaging, neglected hygienic measures adapted during processing. Presence and multiplication of such microorganisms especially aerobic spore-formers bacteria in UHT milk during storage is not only of concern as a public health hazard, but also as a main cause of economic losses through 
spoilage of such products, rendering them unsuitable for human consumption (Khan and Natarajan, 1986). The presence of coliform organisms in UHT is considered as a bad index for the lower hygienic quality and leads to deterioration of the product and causing public health hazards (Saudi et al., 1990). Fungal contamination of UHT milk is indicative for errors in storage and defects in packaging processes, moreover, multiplication of these fungi in UHT milk during storage may induce undesirable flavours, poor appearance and discolouration (Bullerman, 1981).

The HACCP plan is the written document which is based up on the principal activity of HACCP and which delineates the procedures to be followed to assure the control of specific process or procedure and holds details of all that is critical to food safety management (Moy et al., 1994). The HACCP plan is drown up by the HACCP team and consists of two essential components, the process flow diagram and HACCP control chart (Mortimore and Wallace 1995). The aim of this work is the application of HACCP system in the production of sterilized milk to produce safe and high quality product.

\section{MATERIALS and METHODS}

The application of HACCP system principles and required tasks were carried out according to ICMSF (1988), Codex (2000) and ISO 22000: (2005) in the processing line of UHT milk on dairy products processing plant in Egypt. Prerequisite programs were established before application of HACCP system. The HACCP system consists of the following seven principles: Principle (1): Conduct a hazard analysis. Principle (2): Determine the critical control points (CCPS). Principles (3): Establish critical limit(s). Principle (4): Establish a system to monitor control of the (CCPs). Principle (5): Establish the corrective action to be taken when monitoring indicates that a particular (CCP) is not under control. Principle (6): Establish procedures for verification to confirm that the HACCP system is working effectively Principle (7): Establish documentation concerning all procedures and records appropriate to these principles and their application. The process flow diagram for U HT milk was constructed and verified by the HACCP team as the following: 
Receiving raw materials (skim milk powder, milk fat) $\rightarrow$ weight and preparing of raw materials

Receiving raw milk $\left(5-10^{\circ} \mathrm{C}\right) \rightarrow$ cooling and storage of raw milk (less than $10^{\circ} \mathrm{C}$ ) $\rightarrow$ filtration $\rightarrow$ Standardization $\rightarrow$ (fat not less than $3 \%) \rightarrow$ Pasteurization $\left(85^{\circ} \mathrm{C} / 15\right.$ second $) \rightarrow$ storage of pasteurized milk $\rightarrow$ UHT treatment $\left(137^{\circ} \mathrm{C} / 4 \mathrm{sec}\right.$.) $\rightarrow$ Storage (aseptic tank less than $\left.10^{\circ} \mathrm{C}\right) \rightarrow$ filling $\rightarrow$ storage (sterilized milk) (Room temp. $25-30^{\circ} \mathrm{C}$ ) $\rightarrow$ Distribution $\rightarrow$ Consumer.

Flow diagram was used to indicate the major steps in UHT milk production; Random samples were taken during monitoring of raw materials.

Random 30 samples from each of (raw milk, skim milk powder, milk fat, pasteurized and UHT milk). Were taken during monitoring the processing line. The samples were directly transferred to the laboratory with minimum of delay under complete aseptic condition. The samples were taken according to (Marshal 1992).

The samples were subjected to the following examination:

\section{- Chemical examination:}

Determination of $\mathrm{pH}$, titratabile acidity, fat, protein, casein, moisture and activity test for detection of antibiotic residue according to (AOAC 1990).

\section{- Microbiological examination:}

The samples were prepared according to the technique recommended by ICMSF (1978) and the following microbiological examination was then applied. Total aerobic bacterial count, total coliform count, staphylococcus aureus count, aerobic spore-forming count and mold count and determination of salmonellae according to Marshal (1992) and ISO (1993).

\section{RESULTS}

The obtained results were recorded in Tables 1-3

Table 1: Statistical analytical results of chemical examination of raw milk, skim milk powder, milk fat, Standardized Pasteurized milk and UHT milk $\mathrm{n}=30$.

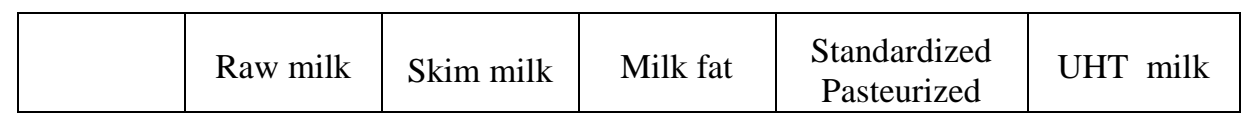




\begin{tabular}{|l|c|c|c|c|c|}
\hline & & powder & & milk & \\
\hline & mean \pm S.E & mean \pm S.E & mean \pm S.E & mean \pm S.E & mean \pm S.E \\
\hline $\begin{array}{l}\text { Activity } \\
\text { test }\end{array}$ & Good & Good & --- & --- & ---- \\
\hline${ }_{\mathrm{P} H}$ & $6.33 \pm 0.028$ & $6.08 \pm 0.02$ & $5.35 \pm 0.06$ & $6.31 \pm 0.044$ & $6.46 \pm 0.025$ \\
\hline Acidity & $0.15 \pm 0.001$ & $0.15 \pm 0.003$ & $0.14 \pm 0.03$ & $0.16 \pm 0.001$ & $0.16 \pm .003$ \\
\hline Fat & $3.45 \pm 0.028$ & 0 & $83.04 \pm 0.15$ & $3.38 \pm 0.036$ & $3.4 \pm 0.031$ \\
\hline Protein & $2.9 \pm 0.019$ & $38.75 \pm 0.4$ & --- & $2.89 \pm 0.015$ & $2.91 \pm 0.018$ \\
\hline Casein & $2.32 \pm 0.013$ & $25.23 \pm 0.26$ & ----- & $2.33 \pm 0.014$ & $2.32 \pm 0.013$ \\
\hline Moisture & --- & $3.05 \pm 0.06$ & $15.22 \pm 0.13$ & ----- & ---- \\
\hline
\end{tabular}

Table 2: Statistical analytical results during monitoring the UHT milk processing line.

\begin{tabular}{|c|c|c|c|c|c|c|}
\hline \multirow{2}{*}{} & \multicolumn{2}{|c|}{ Raw milk } & \multicolumn{2}{c|}{ Pasteurized milk } & \multicolumn{2}{c|}{ UHT milk } \\
\cline { 2 - 7 } & $\begin{array}{c}\text { Receiving } \\
\text { temp. }{ }^{\circ} \mathrm{C}\end{array}$ & $\begin{array}{c}\text { Storage } \\
\text { temp. }{ }^{\circ} \mathrm{C}\end{array}$ & $\begin{array}{c}\text { Pasteurizati } \\
\text { on temp }{ }^{\circ} \mathrm{C} / \\
15 \text { seconds }\end{array}$ & $\begin{array}{c}\text { Cooling } \\
\text { temp. }{ }^{\circ} \mathrm{C}\end{array}$ & $\begin{array}{c}\text { Sterilization } \\
\text { temp }{ }^{\circ} \mathrm{C} / \\
4 \text { seconds }\end{array}$ & $\begin{array}{c}\text { Storage } \\
\text { temp. }{ }^{\circ} \mathrm{C}\end{array}$ \\
\hline Min & 5 & 3 & 85 & 6 & 137 & 5 \\
\hline Max & 9 & 5 & 85 & 8 & 139 & 10 \\
\hline Mean \pm S.E. & $7.4 \pm 0.25$ & $3.96 \pm 0.16$ & 85 & $7.25 \pm 0.18$ & $137 \pm 0.24$ & $7.15 \pm 0.28$ \\
\hline $\begin{array}{c}\text { Normal } \\
\text { value }\end{array}$ & Less than 10 & $2-5$ & $\begin{array}{c}\text { Not less } \\
\text { than } 85\end{array}$ & Less than 8 & $\begin{array}{c}\text { Not less } \\
\text { than } 135\end{array}$ & Less than 10 \\
\hline
\end{tabular}

Table 3: Of raw milk, skim milk powder, milk fat, Pasteurized milk and UHT milk $\mathrm{n}=30$

\begin{tabular}{|c|c|c|c|c|c|c|c|c|c|c|c|}
\hline $\begin{array}{l}\text { Type of } \\
\text { samples }\end{array}$ & \multicolumn{2}{|c|}{ Raw milk } & \multicolumn{2}{|c|}{ Skim milk powder } & \multicolumn{2}{|c|}{ Milk fat } & \multicolumn{3}{|c|}{ Pasteurized milk } & \multicolumn{2}{|c|}{ UHT milk } \\
\hline counts & $\begin{array}{c}\text { Positive } \\
\text { Samples } \\
\%\end{array}$ & $\begin{array}{l}\text { Mean } \pm \\
\text { S.E }\end{array}$ & $\begin{array}{c}\text { Positive } \\
\text { Samples } \\
\%\end{array}$ & $\begin{array}{l}\text { Mean } \pm \\
\text { S.E. }\end{array}$ & $\begin{array}{c}\text { Positive } \\
\text { samples } \\
\%\end{array}$ & $\begin{array}{c}\text { Mean } \pm \\
\text { S.E } .^{(a)}\end{array}$ & $\begin{array}{c}\text { Positive } \\
\text { samples } \\
\%\end{array}$ & $\begin{array}{c}\text { Mean } \\
\stackrel{ \pm}{ \pm} \text { S.E. }\end{array}$ & $\mathrm{R} \%$ & $\begin{array}{c}\text { Positive } \\
\text { samples } \\
\%\end{array}$ & $\begin{array}{l}\text { Mean } \pm \\
\text { S.E. }\end{array}$ \\
\hline $\begin{array}{c}\text { Total } \\
\text { aerobic } \\
\text { bacteria }\end{array}$ & 100 & $\begin{array}{c}3.4 \times 10^{5} \\
\pm \\
1.7 \times 10^{5}\end{array}$ & 100 & $\begin{array}{c}3.8 \times 10^{2} \\
\pm \\
1.5 \times 10^{2}\end{array}$ & 100 & $\begin{array}{c}7.3 \times 10 \\
\pm \\
0.5 \times 10\end{array}$ & 100 & $\begin{array}{c}2.8 \times 10^{3} \\
\pm \\
8.5 \times 10^{2}\end{array}$ & 99.18 & 00 & 00 \\
\hline
\end{tabular}




\begin{tabular}{|c|c|c|c|c|c|c|c|c|c|c|c|}
\hline $\begin{array}{c}\text { Total } \\
\text { coliform }\end{array}$ & 100 & $\begin{array}{c}3.2 \times 10^{4} \\
\pm \\
1.9 \times 10^{4}\end{array}$ & 20 & $\begin{array}{c}1.8 \times 10 \\
\pm \\
0.15\end{array}$ & 40 & $\begin{array}{c}3.2 \times 10^{3} \\
\pm \\
5.4 \times 10^{2}\end{array}$ & 20 & $\begin{array}{c}9.1 \times 10^{2} \\
\pm \\
7.7 \times 10^{2}\end{array}$ & 97.16 & 00 & 00 \\
\hline Staphaureus & 100 & $\begin{array}{c}6.5 \times 10^{2} \\
\pm \\
1.8 \times 10^{2}\end{array}$ & 00 & 00 & 30 & $\begin{array}{c}3.2 \times 10^{2} \\
\pm \\
2.6 \times 10^{2}\end{array}$ & 26 & $\begin{array}{c}5.1 \times 10 \\
\pm \\
2.1 \times 10\end{array}$ & 92.15 & 00 & 00 \\
\hline $\begin{array}{c}\text { Spore } \\
\text { forming }\end{array}$ & 100 & $\begin{array}{c}3.9 \times 10^{2} \\
\pm \\
2 \times 10\end{array}$ & 40 & $\begin{array}{c}1.4 \times 10 \\
\pm \\
0.6 \times 10\end{array}$ & 40 & $\begin{array}{c}2.3 \times 10 \\
\pm \\
0.8 \times 10\end{array}$ & 60 & $\begin{array}{c}7.3 \times 10 \\
\pm \\
0.7 \times 10\end{array}$ & 81.28 & 5 & $\begin{array}{c}3.4 \times 10 \\
\pm \\
0.6 \times 10\end{array}$ \\
\hline Mold & 36 & $\begin{array}{c}1.9 \times 10^{2} \\
\pm \\
5.6 \times 10\end{array}$ & 33.33 & $\begin{array}{c}4.8 \times 10 \\
\pm \\
0.6 \times 10\end{array}$ & 90 & $\begin{array}{c}4.1 \times 10^{3} \\
\pm \\
6.5 \times 10^{2}\end{array}$ & 00 & 00 & 100 & 0 & 0 \\
\hline
\end{tabular}

a: standard error of mean

$\mathrm{R}$ : reduction rate 
Form (1) : HACCP plan for Sterilized Milk

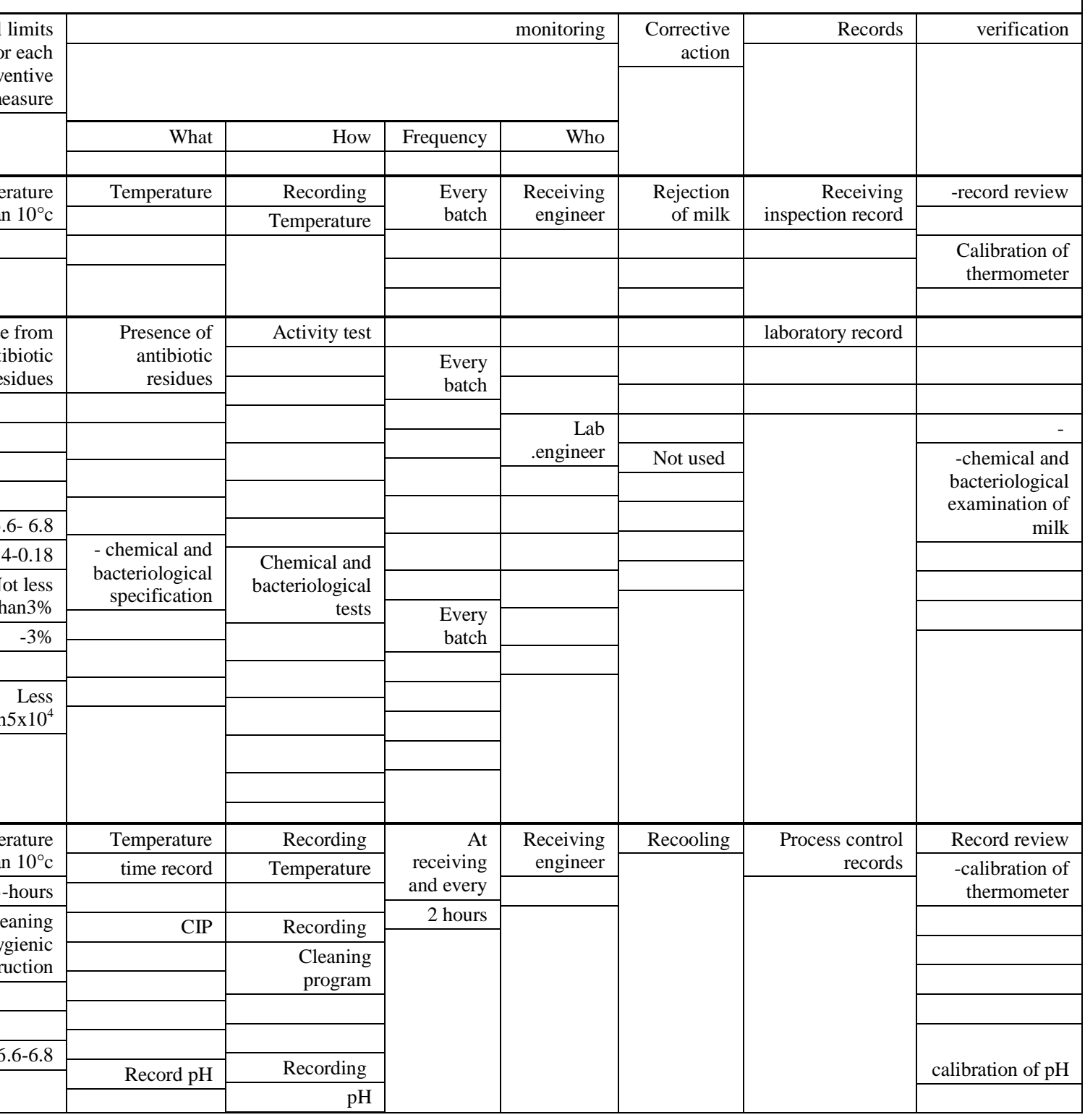




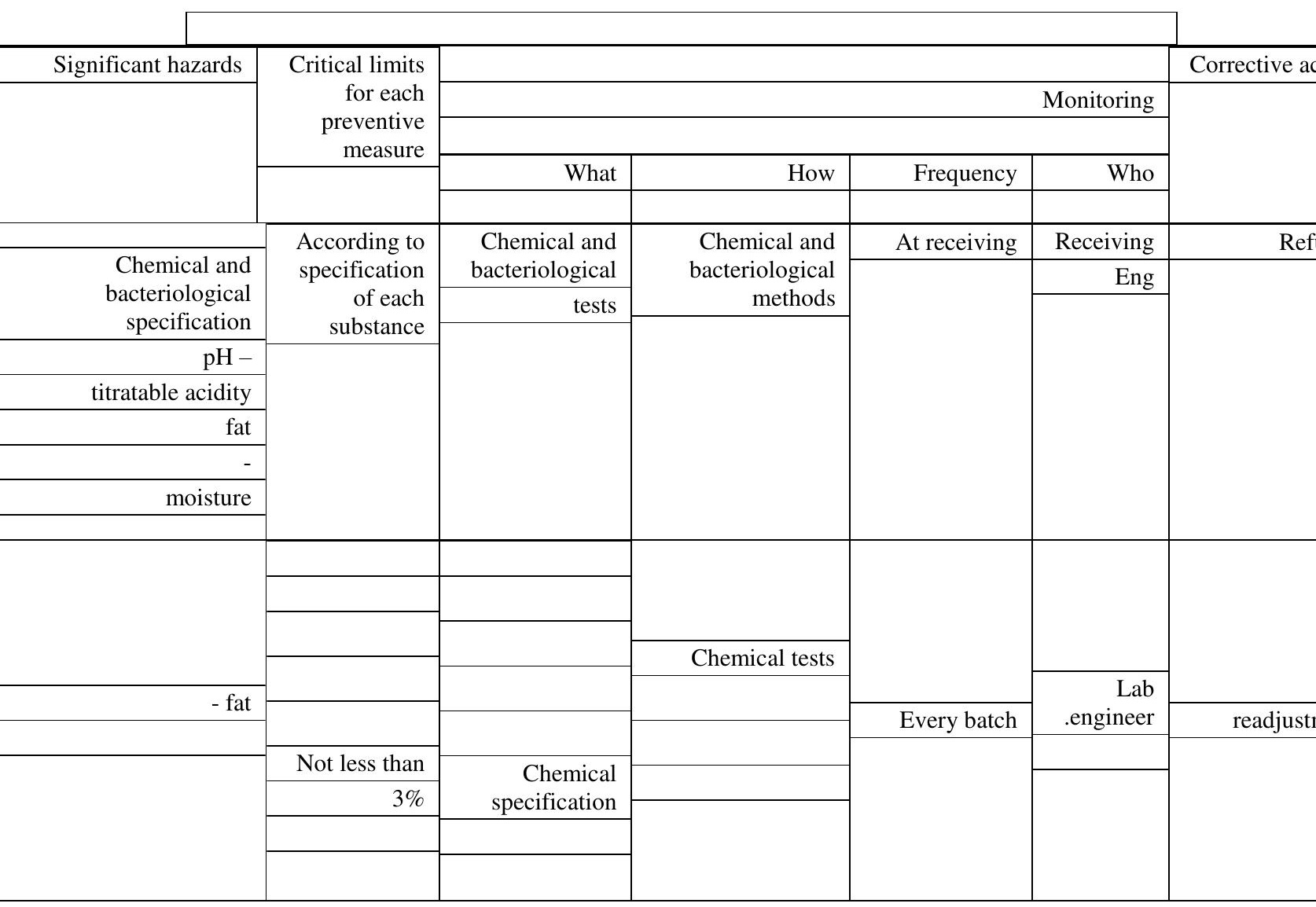




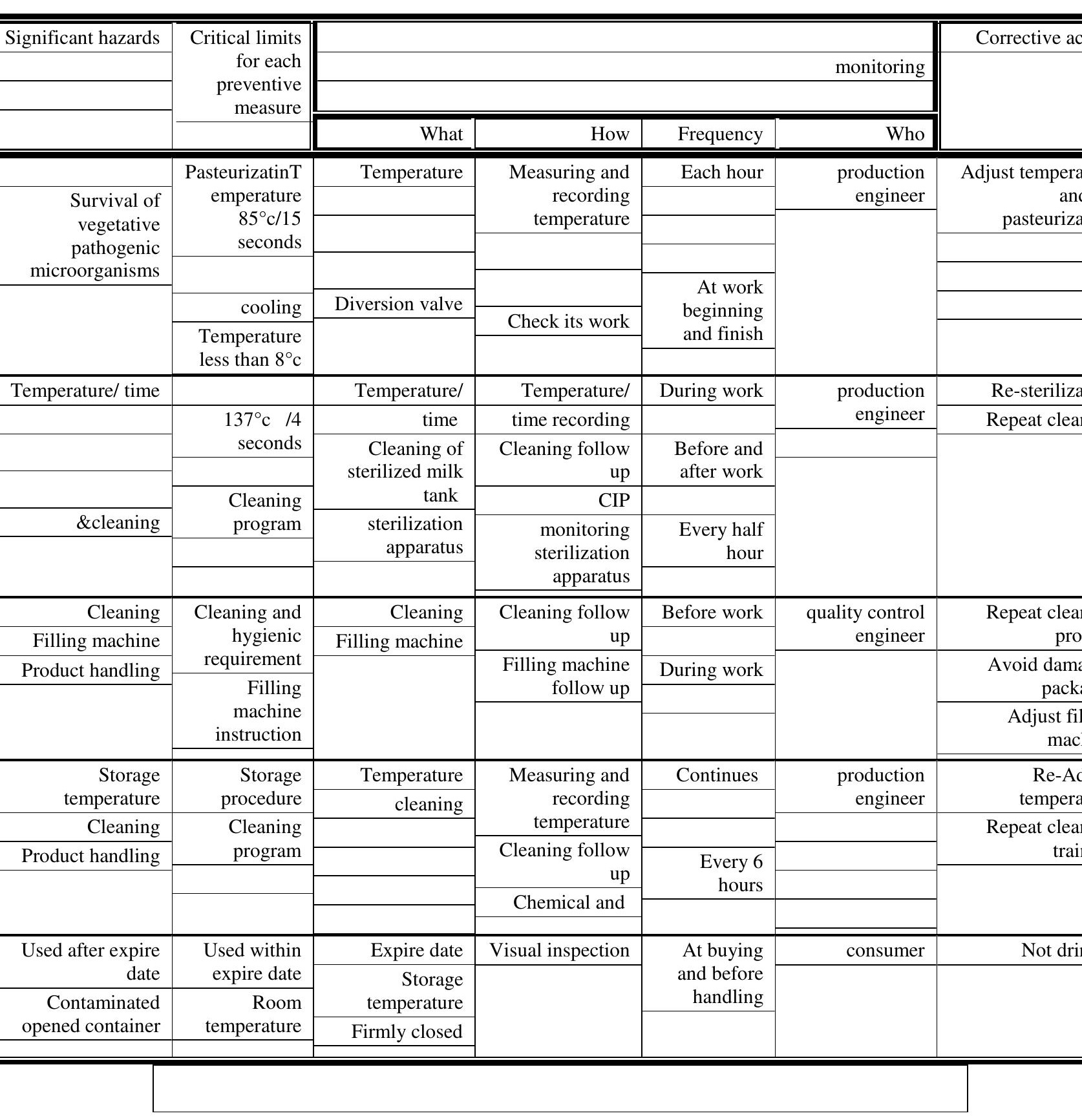




\section{DISCUSSION}

\section{Hazard analysis:}

(Receiving-cooling - storage, preparation and standardization):

The results in Table 1 showed that the mean values of $\mathrm{pH}$, acidity, fat, protein, and casein in raw milk were $6.33 \pm 0.028$, $0.15 \pm 0.001,3.45 \pm 0.028,2.9 \pm 0.019$ and $2.32 \pm 0.013$ respectively. All results were within acceptable limits according to E S (2005). From the data present in Table 1 it is evident that all samples were with good results for the activity test for detection of antibiotic residues in milk. Test for antibiotic residues were carried out to prevent problems with allergic reaction to antibiotic (Varnam and Sutherland 1994). While data present in Table 2 showed that the mean values of receiving and storage temperature ${ }^{\circ} \mathrm{C}$ of raw milk were $7.4 \pm 0.25$ and $3.96 \pm 0.16$ respectively. Raw milk was often implicated in outbreaks of staphylococcal intoxication before rapid cooling of milk and pasteurization become accepted practices (Bryan, 1983). Raw milk transported to the plant in tankers and may be subjected to long transport times and variety of temperatures that may lead to microbial growth and production of microbial toxins that will not be destroyed by subsequent pasteurization process hence control of raw milk delivery is a critical control point (CCP) (ICMSF 1988). The mean values of $\mathrm{pH}$, acidity, fat, protein, casein and moisture in skim milk powder were $6.08 \pm 0.02,0.15 \pm 0.003$, $0,31.75 \pm 0.4,25.23 \pm 0.26$ and $3.05 \pm 0.06$, respectively. this comply with ES (2005) which stated that fat should be not more than $1.5 \%$, moisture not more than $5 \%$, acidity not more than $1.5 \%$ and protein not less than $34 \%$. While the mean value of $\mathrm{pH}$, acidity, fat and moisture in milk fat were $5.35 \pm 0.06,0.14 \pm 0.03,83.04 \pm 0.15$ and $15.22 \pm 0.13$ respectively. This comply with ES (2005) which stated that fat should be not less than $80 \%$, moisture not more than $16 \%$ and acidity not more than $0.1 \%$. The chemical composition of raw milk affects the nature of the final sterilized milk so it is general practice to standardized milk composition to ensure consistency and maximum yield. Standardization was by addition of skim milk powder or milk fat.

The data present in Table 3 showed that the mean values of total aerobic bacterial count (cfu/ml), coliform count, staphylococcus aureus count, spore forming count and mold count in raw milk samples were $3.4 \times 10^{5} \pm 1.7 \times 10^{5}, 3.2 \times 10^{4} \pm 1.9 \times 10^{4}, 6.5 \times 10^{2} \pm 1.8 \times 10^{2}, 3.9 \times 10^{2}$ $\pm 1.7 \times 10^{2}$, and $1.9 \times 10^{2} \pm 5.6 \times 10$, respectively. Salmonella could not be detected. Nearly similar results obtained by Abdel-Hafiez (2006), while 
higher results were obtained by El-Shishnagui et al. (2001). Presence of large numbers of coliform bacteria in raw milk provides an index of the poor hygienic condition under which milk is produced (Richer et al., 1992). Raw milk should be purchased from inspected and approved suppliers and should be stored and distributed under conditions that prevent microbial growth and/or contamination (Hayes 1992). The data present in Table (3) showed that the mean values of total aerobic bacterial count $(\mathrm{cfu} / \mathrm{ml})$, total coliform count,staphyloccus aureus count, spore forming count and mold count were $3.8 \times 10^{2} \pm 1.5 \times 10^{2}, 7.3 \times 10 \pm 0.5 \times 10,1.8 \times 10 \pm 0.15,3.2 \times 10^{3} \pm$ $5.4 \times 10^{2}, 00,3.2 \times 10^{2} \pm 2.6 \times 10^{2}, 1.4 \times 10 \pm 0.6 \times 10,2.3 \times 10 \pm 0.8 \times 10,8 \times 10 \pm$ $0.6 \times 10$ and $4.1 \times 10^{3} \pm 6.5 \times 10^{2}$ in skim milk powder and milk fat receptively, Salmonella could not be detected in milk powder and milk fat. this comply with ES(2005) which stated that milk powder must be free from pathogenic microorganisms, Salmonella and E. coli, total bacterial count not more than $10 \mathrm{cfu} / \mathrm{gm}$ and mold count not more than $10 \mathrm{cfu} / \mathrm{gm}$. while milk fat must be free from pathogenic microorganisms, E. coli, spoilage bacteria and mold, coliform not more than10cfu/gm

\section{Pasteurization:}

The data present in Table 2 showed that he pasteurization temperatures were $85 \mathrm{c}^{\circ}$ for exactly 15 seconds. Almost all potential microbiological hazards can be eliminated with a heat treatment (pasteurization). Pasteurization has proved to be successful as CCP to control zoonoses as well as food borne pathogens such as Campylobacter and Salmonella (IDF 1994).

Table 1 reported that the mean values of $\mathrm{pH}$, acidity, fat, protein and casein in standardized pasteurized milk were $6.31 \pm 0.044$, $0.16 \pm 0.001,3.38 \pm 0.036,2.89 \pm 0.015$ and $2.33 \pm 0.014$ respectively. All results comply with (ES 2005) which stated that fat not less than $3 \%$ in full cream pasteurized cow milk

The data in Table 3 showed that the mean values of total aerobic bacterial count $(\mathrm{cfu} / \mathrm{ml})$, coliform count, staph aureus count, spore forming count, and mold count in standardized pasteurized milk were $2.8 \times 103 \pm 8.5 \times 102,9.1 \times 102 \pm 7.7 \times 102,5.1 \times 10 \pm 2.1 \times 10$ and $7.3 \times$ $10 \pm 0.7 \times 10$, respectively. Salmonella and mold could not be detected. The present count may be due to the presence of spore forming bacteria as well as thermoduric count which can resist the pasteurization temperature. Lower results were obtained by Abdel- Hafiez and Ragab (2004), Abdel Hafiez (2006). All results were within control limits according to HACCP plan form (1) and comply with (ES 2005). Which stated that pasteurized milk should be free from pathogenic 
microorganisms. The reduction rate in pasteurized milk samples were 99.18, 97.16, 92.15, 81.28 and 100 in total aerobic bacterial, coliform, staphyloccus aureus, Spore forming and mold counts respectively. In most developed countries; fresh milk is rapidly chilled and stored at refrigeration temperatures in an attempt to limit microbial growth. Prolonged refrigeration storage of milk has been resulted in problems of quality for dairy industry (Swart et al., 1989).

Heat resistant spore formers are most important microorganisms as these spores are able to survive the pasteurization process, germinate at temperature as low as $7^{\circ} \mathrm{C}$ followed by auto growth and subsequent spoilage of milk faster than mesophilic types (Sutherland and Murdach, 1995).

\section{Cooling:}

Illustrated data present in Table 2 showed that the cooling temperature of pasteurized milk ranged from $6^{\circ} \mathrm{C}$ to $8^{\circ} \mathrm{C}$ with a mean value of $7.25 \pm 0.18$. Pasteurized milk has a relatively short life (7-10 days) and should be used immediately, or stored in the refrigerator. Pasteurization does not destroy all of the microorganisms; therefore the milk has to be cooled rapidly to prevent the growth of surviving bacteria.

\section{UHT treatment:}

While pasteurization conditions effectively eliminate potential pathogenic microorganisms, it is not sufficient to inactivate the thermoresistant spores in milk. The term sterilization refers to the complete elimination of all microorganisms. The chemical and microbiological tests were carried out for verification of that the final product (UHT milk) achieved required quality and safety. The data present in Table (1) showed that the mean values of $\mathrm{pH}$, acidity, fat, protein and casein in examined sterilized milk samples were $6.46 \pm$ $0.025,0.16 \pm 0.003,3.4 \pm 0.031,2.91 \pm 0.018$ and $2.32 \pm 0.013$, respectively. All results comply with (ES 2005). Which stated that fat not less than $3 \%$ in full cream sterilized milk and acidity not more than $0.17 \%$.

Table 2 showed that the UHT temperature ranged from $137^{\circ} \mathrm{C}$ to $139^{\circ} \mathrm{C}$ with a mean value of $137 \pm 0.024$ for exactly 4 seconds. The basis of UHT milk is the sterilization of milk before packaging, then filling into pre-sterilized containers in a sterile atmosphere.

Data in Table 3 showed that the mean values of total bacterial count $(\mathrm{cfu} / \mathrm{ml})$ and total spore forming count in examined sterilized milk samples were: $00,3.4 \times 10 \pm 2.4$ respectively. Coliform, staphyloccus aureus, mold and salmonella could not be detected. The reduction rate in 
sterilized milk samples were 100,100, 100, 91.28 and 100 in total aerobic bacterial, coliform, staphylococcus aureus, spore forming and mold counts respectively. All results were within control limits according to HACCP plan form (1) and comply with (ES 2005). This stated that UHT milk should be free from pathogenic microorganisms, total bacterial count not more than $10 \mathrm{cfu} / \mathrm{ml}$ and free from $\mathrm{E}$ coli. Higher results were obtained by (El-Asuoty 2006).

For production of high quality UHT milk high quality raw milk should be used in its manufacture and strict attention to sterilization procedure and packaging materials should be applied (Farahnik, 1982). Presence and multiplication of aerobic spore formers bacteria in UHT milk during storage is not only of concern as a public health hazard but also cause economic losses through spoilage of such product rendering them unsuitable for human consumption (Khan and NataraJan, 1986 and Abo-Donia et al., 1985). The presence of coliform organisms in UHT milk is considered as a bad index for hygienic quality and lead to deterioration of the product and causing public health hazards (Saudi et al., 1990). UHT milk may be contaminated with such organisms due to inefficient heat treatment of processed milk, faults in packaging, neglected hygienic measures during processing or using improperly cleaned and sterilized equipment or due to leakage of package during transportation and storage (Farahnik, 1982). Food handling personnel play an important role in ensuring food safety through out the chain of production, processing, storage and preparation. Mishandling and disregard of hygienic measures on their part may enable pathogens to come in contact with food and in some cases to survive and multiply in sufficient numbers to cause illness in the consumer (WHO, 1980). Staphylococcus aureus is a good indicator of the personal hygiene of workers with respiratory infections and suppuration (Kamat et al., 1991). Contamination of UHT milk with moulds is indicative of the neglected hygienic measures applied during processing, packaging and storage and constitutes a public health hazard (Lee, 1984).

\section{Filling:}

A septic filling of UHT milk is the most important factor of contamination (langefeld, and Bolle, 1979). The sterilized milk was filled on laminated paper tetrapak. Sterilization and aseptic packaging is the goal for most milk products, the most common packaging material for both pasteurized and UHT milk is glass bottles sealed with either foil or metal caps, although plastic bottles, plastic bags, card board cartons and laminated paper tetrapak are all used. 


\section{Storage:}

The results of Table1 showed that the storage temperature of UHTmilk ranged from 5 to $10{ }^{\circ} \mathrm{C}$ with a mean value of $7.15 \pm 0.28$. Sterilized milk will keep unopened for several months (6 months), but once opened the milk must be kept refrigerated and used within 4-5 days.

\section{Distribution-Consumers}

Control during distribution to prevent post contamination and control hazard at customer by increase his awareness to follow instruction printed in the package especially expiry date and method of preservation.

It can be concluded that the raw milk should be collected and maintained in a good hygienic condition. If the raw milk is not be used immediately, it should be refrigerated to minimize multiplication of bacteria. The raw milk should under go a full pasteurization or equivalent process, good conditions of hygiene should be maintained through out UHT production, distribution and storage until consumption to prevent contamination. A HACCP based risk assessment and good manufacturing practice should be employed for all stages of production and handling from the farm to the consumer.

\section{REFERENCES}

AbdEl-Hafiez, E.M.E. and Ragab, Mervat, K.I. (2004): Application of Hazard Analysis Critical Control Point (HACCP) system to produce high quality and safe plain yoghurt. Alex. J. Vet, Vol 21 No.1, 168-185.

AbdEl-Hafiez, E.M.E. (2006): Evaluation of quality and safety of feta cheese produced by application of quality assurance program. Benha Vet. Med. J, Vol. 17, No. I,

Abo-Donia, S.A.; El-Dosa, M.; Sirry, I. and Harfaush, S. (1985): Milk lipolytic bacteria IA. Quantitative and qualitative study on lipolytic activity of four bacterial cultures. Alex. J. Agric. Res., 29 (3): 257.

AOAC (1990): Official Methods of Analysis, 931,15 ${ }^{\text {Th }}$ Ed. Public AOAC, Box 540 Benjamin Franklin station, Washington, 4, DC.

Bryan, F.L. (1983): Epidemiology of milk borne diseases J. Food Prot. 46.637-649. 
Bullerman, L.B. (1981): Public health significance of mold and mycotoxins in fermented dairy products. J. Dairy Sci., 69: 2439. Codex ALimentarius (2000): Milk and Milk Products Joint FAO/WHO food standards programme, Codex Alimentarius Commission, $2^{\text {nd }}$ Ed., Vol. 12 World Health Organization, Rome, p.42-45., Rome.

Early, R. (1997): Putting HACCP into practice International Journal of Dairy Technology Vol. 50. No. I February.

Egyptian Standard specification (2005): Egyptian Standards Hazard analysis critical control point system and guide lines for its application. Codex: 1-1969 Rev. 4.2003 Es: 3778/ 2005.

El-Asuoty, M.S. (2006): Quality assurance procedures of Ultra Heat Treated milk at local markets. A thesis M.V. Sci, dept. Food hyg, Fac. Vet. Med. Sci. Alex. Uni. (2006).

El-Shishnagui, Sawsan, M.L.; Saleh, S.K. and Fathalla, M.G. (2001): The microbiological quality of raw and pasteurized milk in Alexandria with special reference to the incidence of sane coldTolerant Pathogens. Bull H.I.P.H, Vol. 11(2): 217-232.

Farahnik, S. (1982): A quality control program for recommendation for UHT milk processing and aseptic packaging of milk and milk by-products Dairy Food Sanit., 2 (11): 454-456.

Hayes, P.R. (1992): Food Microbiology and Hygiene $2^{\text {nd }}$ Ed. Elsevier science publisher LTD England.

ICMSF (International Commission on Microbiological Specification for Foods (1978): Microorganisms in foods Vol. I Univ. of Toronto press, Toronto and Buffalo, Canada.

ICMSF, International Commission of the Microbiological specification of Foods (1988): Microorganisms in food. Vol. 4: Application of the hazard analysis critical control point (HACCP) system to ensure microbiological safety and quality Black well scientific publications.

IDF (International dairy federation) (1994): Recommendation for the hygienic manufacture of milk and milk based products. Bull. Int. Dairy Fed. 292, 41.

ISO (1993): General guidance on methods for the detection of salmonella. ISO 6579: 1993 (E).

ISO 22000 (2005): Food safety management systems requirements for any organization in the food chain (Iso 22000: 2005) National Standards Authority of Ireland glasnevin, Dublin 9 Ireland. 
Kamat, M.Y.; Sulebele, G. and Nirupama, Sabnis (1991): Acomparative evaluation of media for enumeration of enterotoxigenic staphylococci by selective enrichment technique. J. Food Sci. Technol., India, 28(6): 381-383.

Kassem, M.; Salem, E.; Ahwal, A.M.; Saddik, M. and Gomaa, N.F. (2002): Application of hazard analysis and critical control point system in the dairy Industry Eastern Mediterranean Health Journal Volume 8, No. I, January 2002.

Khan, I.M. and Natarajan, T. (1986): Incidence of aerobic spore formers in milk. Madras Agric J. 73 (10): 570-572.

Langefeld, l.P.M. and Bolle, A.C. (1979): Duration of the preincubation period in the sterility control of UHT sterilized milk. The Netherlands milk Dairy J.33:1172-180.

Lee, C.M. (1984): Spoilage microorganisms encountered in UHT processed milk-Chinese J. Microbiol. Immunol. 17(2): 86-91.

Marshall, R.T. (1992): Standard Methods for the examination of dairy products, $16^{\text {th }}$ Edition American Public Health Association, Washington DC, 2005, 1015 Fifteeth Street N.W.

Mortimore, S. and Wallace, C. (1995): HACCP A practical approach. Chapman and Hall. 2-6 Boundary Row London.

Moy, G.; Kaferstin, F. and Motar, J. (1994): Application of HACCP to food manufacturing some consideration on harmonization through training. Food Control vol. 5 number 3, p. 131-139.

Richer, R.L.; Ledford, R.A. and Murphy, S.C. (1992): Compendium Methods for the Mcrobiological Examination of Foods $3^{\text {rd }}$. 387856, American Public Health Association D.C.

Saudi, A.M.; Salam, S.S.; El-Essawy, H.A. and Hafez, N.M. (1990): Bacterialogical quality of UHT milk at Giza. Alex J. Vet-Med., 6(1): 39-45.

Sutherland, A.D. and Murdach, R. (1995): Seasonal occurrence of psychrotrophic Bacillus species in raw milk, and studies on the interaction with mesophilic Bacillus species. International J.Food Microbiol., 21: 279-292.

Swart, G.J.; Jooste, P.J. and Mastert, J.F. (1989): The occurrence and seasonal distribution of psychrotrophic and certain mesophilic bacterial types in the bulk milk supply of the Pretoria Oreg. Suid-Afrikaans Tydskrif Virsiwelkunde, 21 (1): 1-8 Dairy Sci. Abstr., 51 (12), (1989). 
Varnam, A.H. and Sutherland, J.P. (1994): Milk and Milk Products technology, chemistry and microbiology, Chapman \& Hall. London-New York-Tokyo.

WHO (World Health Organization) (1980): "Health examination of food handling personnel" Report of working group Copenhagen. WHO Regional office for Europe. 